ТИПИ ЖИТТЄВИХ СТРАТЕГІЙ ОСОБИСТОСТІ В УМОВАХ СУСПІЛЬНОÏ НЕСТАБІЛЬНОСТІ

\title{
TYPES OF LIFE STRATEGIES OF A PERSON IN CONDITIONS OF SOCIAL INSTABILITY
}

\begin{abstract}
Стаття присвячена проблемі побудови життєвого шляху особистістю в умовах суспільної нестабільності та розгляду основних способів реалізації нею життевих иінностей у соціумі. Ця проблематика розглядається в контексті діалогу особистості із соціумом: аналізуються як наявн нестабільні умови існування, що породжують виклики для особистості, так і їі можливості по-різному відповідати на останні. Суспільну нестабільність розглянуто як системне явище, що складається із 5 підсистем функціонування суспільства: свідомісної (ціннісноі), політичної, економічної, соціальної та культурної (гуманітарноі). Порушення у функціонуванні однієї чи кількох з них породжує переживання особистістю невизначеності щодо власного і соціального майбутнього, тією чи іншою мірою впливаючи на їі способи реалізації життєвих цінностей та чілей. У разі розгляду особистісного виміру явища життєвих стратегій зроблено акцент на важливості контакту особистості із персональним світом в умовах переживання невизначеності щодо власного майбутнього, що, своєю чергою, дозволяє певною мірою стабілізувати життя і займати стосовно нього авторську позицію. Показано наявні протиріччя у підходах у разі аналізу життєвих стратегій та зроблено спробу вирішити їх шляхом зведення розуміння цього поняття до більш загального. Виокремлено 2 типи життєвих стратегій: реактивну та проактивну. Запропоновано визначення обох типів стратегій та зазначено, що вони взаємодоповнюють одна одну. Якщо реактивна життєва стратегія відповідає за адаптацію особистості до соціуму, то проактивна - за неадаптивну актив ність, що дає можливість особистості реалізовувати в процесі побудови життєвого шляху персональні цінності та впливати на соціальне середовище. Також зроблено припущення про зв'язок проактивної життєвої стратегії з просоціальністю та ї̈ позитивну роль у стабілізації життя і розвитку як самої особистості, так і суспільства загалом.
\end{abstract}

Ключові слова: життєві стратегіі, суспільна нестабільність, реактивність, проактивність, екзистенція.

The article is dedicated to the problem of build ing a life path by a person in conditions of social instability and to the consideration of basic ways of his/her realization of life values in society. This issue is considered in the context of a dialogue between the person and society: it analyzes both the existing unstable living conditions that create challenges for the person, and his/her ability to respond differently to the latter. Social instability is seen as a systematic phenomenon that comprises 5 subsystems of functioning of society: conscious (value-related), political, economic, social and cultural (humanitarian). Dysfunction of one or more of them makes a person feel a sense of uncertainty regarding their own and social future, to some extent affecting their ways of realizing life values and goals. When considering a personal dimension of the phenomenon of life strategies, emphasis is placed on the importance of a personal contact with an inner world of personality in the face of uncertainty about their own future, which, in turn, allows to stabilize life and take an author's position on it. The existing contradictions in the approaches in the analysis of life strategies are shown and an attempt is made to solve them by reducing the understanding of this concept to a more general one. There are 2 types of life strategies: reactive and proactive. The definition of both types of life strategies is proposed and it is noted that they complement each other. While the reactive life strategy implies the adaptation of the person to society, the proactive strategy embraces non-adaptive activities, which allows the person to realize personal values in the process of building a life path and influence the social environment. It has also been suggested that proactive life strategy is linked to prosociality and supposed that it plays a positive role in stabilizing the life and development of both the individual and society as a whole.

Key words: life strategies, social instability, reactivity, proactivity, existence.
Питання можливостей та способів реалізації особистістю життєвих цінностей задля досягнення задоволеності результатом власного життя $€$ одним з фундаментальних у психологічній науці. Сучасний рівень розвитку суспільства дає людині широкі можливості для самостійного вибору і побудови власного життєвого шляху. Проте широке поле можливостей і свобода вибору особистістю власного життєвого шляху може значно обмежуватися тими процесами, що відбуваються в нашому суспільстві нині. Українське суспільство переживає кризовий стан, що зумовлений низкою подій, як-то: наслідки двох політичних революцій, процес довготривалої гібридної війни, кри- зові соціальні та економічні наслідки тривалих карантинних обмежень у зв'язку із COVID-19. Низка вчених провели дослідження, в яких було виявлено, що наше суспільство переживає стан аномії та кризи, перебуває у стані нестабільності соціальної структури, значна частина населення перебуває у стані невизначеності цивілізаційно-культурних орієнтацій, відсутності соціальної довіри у надособистісних та міжособистісних відносинах, відсутності соціальної відповідальності, руйнування старої ідентичності та несформованості нової [1; 2; 3]. Тому в таких умовах важливим стає питання: як особистість будує власний життєвий шлях, яким способом реалізує життєві 
цінності за допомогою тієї чи іншої життєвої стратегії.

Дослідженням життєвих стратегій займалися низка вчених, розглядаючи їх як: вирішення суперечностей між вимогами суспільства і потребою особистості у самореалізації (К.А. Абульханова-Славська, К.Л. Мілютіна), типи орієнтацій особистості у соціумі (К. Хорні), життєвий сценарій (Е. Берн, С. Карпман), соціальні скрипти (X. Менг), способи діалогічної взаємодії особистості із соціумом (А. Ленгле, В. Франкл), способи реалізації особистістю свободи (Р. Мей, Ж.-П. Сартр, Е. Фромм), життєтворчість особистості (О.Д. Джура, Д.О. Леонтьєв, В.А. Роменець, Т.М. Титаренко, Н.В. Фоміна, А.М. Фомінова, М.О. Щукіна), способи формування особистістю власного майбутнього (М.А. Ляхова, Т.В. Примак, Т.Є. Резнік, Ю.М. Резнік), способи самоздійснення особистості на основі її ціннісних орієнтацій (Є.О. Васіна), спосіб організації життя особистістю в актуальній соціальній та життєвій ситуації (А.О. Волокітіна, Ю.А. Зубок, Ю.В. Мельник, В.І. Чупров).

Незважаючи на всю різноманітність поглядів на сутність життєвих стратегій, ми можемо виокремити їх загальні ознаки та функції, які так чи інакше простежуються в різних підходах. Життєві стратегії: 1) визначають життєвий шлях особистості, її майбутнє; 2) передбачають різну міру включення особистості в процес побудови свого життєвого шляху; 3) передбачають пошук особистістю оптимальних шляхів до взаємодії із соціумом, спрямованих на реалізацію життєвих цілей, цінностей, планів, смислів.

Частина дослідників тісно пов'язують життєві стратегії із поняттями суб'єктності, самореалізації, особистісної зрілості (К.А. Абульханова-Славська, А.О. Волокітіна, Ю.А. Зубок, B.І. Чупров), тому наявність стратегії передбачає контроль особистості над власним життям і особистісне зростання. Проте не зовсім зрозуміло, як можна охарактеризувати ті випадки, коли особистість свідомо чи несвідомо вибирає пасивну позицію в процесі побудови власного життєвого шляху. Причиною вибору такої стратегії може виступати не лише відсутність особистісної зрілості чи невміння реалізовувати власні цілі та цінності у взаємодії із соціумом. Інколи причиною такої пасивної стратегії може виступати прагматична доцільність чи відсутність ресурсів для проактивної взаємодії із кризовими, нестабільними соціальними умовами існування [12]. За допомогою життєвої стратегії особистість може реалізовувати свій потенціал, особистісно зростати, також життєва стратегія може допомагати людині виживати біологічно у складних життєвих ситуаціях. Тому, на нашу думку, життєві стратегії потрібно розглядати як більш загальне явище, яке може мати різні варіанти прояву в умовах суспільної нестабільності.

Мета статті - теоретично визначити основні типи життєвих стратегій та їх роль у побудові життевого шляху особистістю в умовах суспільної нестабільності.

Під життєвою стратегією ми будемо розуміти способи реалізації особистістю життєвих цінностей та цілей. Особистість вибудовує свій життєвий шлях на основі тих цінностей, які засвоює в ході первинної соціалізації у сім'ї [4]. Також особистість у процесі свого розвитку взаємодіє з іншими соціальними групами, які більшою чи меншою мірою впливають на їі уявлення про значиме в житті. Проте цінності різних соціальних груп можуть протирічити одна одній, так само і породжувати внутрішній конфлікт у самій особистості. Тому особистість не лише пасивно засвоює цінності соціуму, а й може вибирати те, що значимо для неї в житті (персональні цінності). І вже на основі цих орієнтирів людина вибирає доступні для неї способи втілення ідеального в реальне життя. Тому у разі вивчення життєвих стратегій потрібно розглядати їх як діалогічне явище, що включає у себе взаємодію персонального (особистісного) світу із соціальним.

у реальному житті людина майже завжди стикається з перепонами на шляху до реалізації власних цінностей, чи-то йдеться про конфлікт з цінностями окремої людини або з цінностями, прийнятими у суспільстві загалом. К.А. Абульханова-Славська зазначає, що в радянські часи особистість не мала можливості (за окремими випадками) реалізовувати індивідуальні (персональні) життєві цінності (вибір відбувався на користь інших, заохочувалась реактивна поведінка у соціумі), тому індивідуалізм (відстоювання власних цінностей) жорстко карався соціальними санкціями. Соціалізація в ці часи відбувалася за наявності чітких соціальних уявлень про те, яким повинно бути життя соціуму. Життя окремої людини не враховувалося як самоцінне, а розглядалося лише у зв'язку з її соціальним боргом, відповідальністю за соціальне благополуччя і соціалістичне майбутнє. 3 розпадом радянського устрою людина отримала свободу самостійно формувати життєвий шлях, можливість більше звертати увагу на індивідуальне буття [5]. Проте руйнація визначеності соціального майбутнього до сих пір ще супроводжується кризовими процесами у суспільстві. Тому наше суспільство можна охарактеризувати як нестабільне, оскільки нині, як ми згадували вище, суспільство перебуває на межі між зруйнованими старими і несформованими новими орієнтирами життя соціуму. Політичні революції, фінансова криза, гібридна війна, ціннісні протиріччя між окремими регіонами нашої країни також привносять поки що більше нестабільності в життя суспільства загалом. 
Суспільна нестабільність 3 точки зору системного підходу визначається як порушення у функціонуванні однієї із підсистем суспільного управління - свідомісної (ціннісної), політичної, економічної, соціальної та культурної (гуманітарної). Елементи суспільної системи знаходяться в ієрархічному підпорядкуванні, тому від стану окремої підсистеми залежить загальний стан життя суспільства [6]. Також суспільна нестабільність визначається як кризовий період у житті суспільства, коли цінності попередніх поколінь втрачають свою актуальність, критерії нормальної поведінки стають менш зрозумілими, що породжує конфлікти між поколіннями [1]. У таких умовах особистість переживає стан тривоги внаслідок втрати визначеності власного майбутнього, втрати ціннісних орієнтирів, нечіткості соціальних норм. Також люди переживають кризу ідентичності та відсутність відчуття власного впливу на життя суспільства. У такий період може ставитися людиною під сумнів постійність і безперервність буття, відбувається дестабілізація уявлень про навколишній світ. Втрата можливості передбачувати майбутнє ускладнює можливість для осмисленого життя окремої людини та реалізації нею власних життєвих цілей [2]. Підсумовуючи вищесказане, ми можемо визначити суспільну нестабільність як такі кризові процеси у функціонуванні суспільної системи, що породжують переживання окремою людиною стану невизначеності щодо власного майбутнього.

Розглянувши складники явища суспільної нестабільності та його вплив на особистість, варто перейти від соціальних умов існування (зовнішнього світу) до персонального виміру буття, можливостей окремої людини впливати на власне майбутнє. Кризові процеси у суспільстві породжують переживання стресу в окремих людей, тому особистість використовує копінг-стратегії або копінг-реакції як спосіб подолання стресових переживань, вирішення проблем і завдань, пов'язаних із ситуацією, що їх породила. Проте копінги відображають лише неперсональну відповідь (реакцію) на стресову ситуацію та не враховують цілісний процес побудови життєвого шляху особистістю, ї̈ персональний діалог із зовнішнім світом [7]. Тому важливіше розглянути життєвий шлях загалом, який хоч і складається із низки ситуацій, проте має якісно іншу характеристику. Можна припустити, що копінг-стратегія може бути складником життєвої стратегії або мати схожі характеристики (якщо людина перманентно орієнтована на зменшення переживання напруги від стресу в актуальних чи потенційних ситуаціях). Проте на основі розгляду копінг-стратегій ми не можемо говорити про зміст і якість життя, тоді як життєві стратегії більш цілісно відобража- ють життєвий шлях особистості з огляду на такі прояви особистості, як: її прагнення до самореалізації та переживання наповненості життя сенсом (К.А. Абульханова-Славська, М.А. Ляхова, Т.Є. Резнік, Ю.М. Резнік).

Оскільки особистість в умовах суспільної нестабільності стикається з перепонами до реалізації власних життєвих цінностей, то постає питання того, які можливості (способи) існують для їх реалізації. У сучасній психології виділяються 2 основні способи діалогу (взаємодії) особистості із зовнішнім (соціальним) світом: реактивний та проактивний [8].

Реактивний спосіб взаємодії передбачає адаптацію особистості до наявних умов життя з мінімальною кількістю витрачених на цей процес ресурсів. У ході реактивної взаємодії поведінка особистості детермінована переважно зовнішніми, ситуативними чинниками та її орієнтацією на загальноприйняті у соціумі традиційні цінності [8; 12]. Завдяки реактивній життєвій стратегії людина значно економить час і психічні ресурси в ході повсякденної взаємодії із соціальним оточенням, що є необхідною умовою для виживання і переживання передбачуваності і послідовності подій власного життя. Повсякденне соціальне життя переважно сповнене стереотипними ситуаціями починаючи від грудного вигодовування, закінчуючи традиціями весільної церемонії, де наші реакції вже закладені в процесі соціалізації [9]. Отже, ми можемо визначити реактивну життєву стратегію особистості як такий спосіб реалізації нею життєвих цінностей та цілей, що визначається цінностями соціального оточення та спрямований на мінімізацію витрат ресурсів у процесі адаптації до наявних умов життя.

Хоча реактивна життєва стратегія допомагає людині адаптуватися до наявних умов життя у соціумі, проте вона має свої обмеження. Орієнтація лише на зовнішні вимоги не враховує персональний вимір людського існування, завдяки якому формується неповторна картина життєвого шляху особистості та відбувається розвиток суспільства. Хоча опора на минулий досвід, можливо, ще допомагає людині виживати, проте стає непродуктивною стратегією для її самореалізації та осмисленого життя, проживання нею екзистенції. У такому разі актуальності набуває протилежна життєва стратегія - проактивна.

Проактивність та проактивний спосіб взаємодії особистості із зовнішнім світом вивчалися вченими в контексті: свободи і відповідальності особистості за реалізацію смислу життя (К. Кольбе, А. Ленгле, Д.О. Леонтьєв, Е. Лукас, Р. Мей, В. Франкл), інтернального локусу контролю (Дж. Роттер), самоефективності (А. Бандура), самоактуалізації особистості (К. Роджерс, А. Маслоу), пропріуму(Г.Олпорт), проактивноїопанувальної 
поведінки (Є.С. Старченкова), суб'єктності (С.Л. Рубінштейн), проактивних копінг-стратегій (Lisa G. Aspinwall, Lisa Fiksenbaum, O.І. Єрзін, Esther R. Greenglass, Yiqun Gan, Miao Miao, Lei Zheng), надситуативної активності особистості (В.І. Аснін, В.А. Петровський), проактивної адаптації особистості (Л.М. Коробка), проактивної поведінки особистості (О.І. Єрзін), неадаптивного типу активності особистості (О.Г. Асмолов).

Проактивний спосіб взаємодії особистості із зовнішнім світом допомагає їй протистояти несприятливим або нестабільним умовам життя, впливати на них і певною мірою їх формувати. Така стратегія стає можливою в разі, якщо особистість усвідомлює власні (персональні) цінності, у протилежному випадку така стратегія буде скоріше просто самоцільним бунтом. Емпіричне дослідження також показує важливість таких особистісних предикторів проактивної поведінки, як: усвідомленість дій, прогнозування наслідків поведінки, внутрішній локус контролю, спонтанність, автономія в прийнятті рішень, метамотивація та внутрішня детермінація поведінки [10]. У цьому ж дослідженні було виділено 2 види спрямованості проактивної поведінки: антисоціальну (деструктивну) і просоціальну (конструктивну проактивність). Тому проактивна поведінка не завжди означає, що людина здійснює особистісний вчинок, який спрямований на розвиток і благополуччя інших людей.

Проте якщо розглядати проактивну життєву стратегію як процес реалізації людиною персональних цінностей, то тут уже не йдеться про асоціальну спрямованість. Згідно з екзистенційною теорією Person, духовне несвідоме $€$ справжньою сутністю людини, контакт з якою допомагає ій максимально сповнити (реалізувати) власну екзистенцію. А. Ленгле зазначає, що чим ближче людина знаходиться в діалозі з власною сутністю, тим більш людяною вона стає [11]. Стаючи собою, людина допомагає іншим встановити контакт із власним персональним, що конструктивно впливає на життя окремої людини і розвиток самого суспільства на локальному рівні.

Спираючись на вищесказане, ми можемо визначити проактивну життєву стратегію як процес реалізації особистістю персональних життєвих цінностей та цілей, що ґрунтується на здатності людини впливати на соціальні умови життя. Завдяки проактивним життєвим стратегіям особистість може більш автентично (персонально) взаємодіяти з іншими людьми, знаходячи нові способи вирішення протиріч між соціальним тиском та власним прагненням сповнити (реалізувати) екзистенцію. Такий вид стратегій спрямований на зміну людиною як власного життя, так і сталих норм взаємодії з оточенням, або навіть зміну соціального порядку на краще, що допомагає особистості вносити персональний вимір у соціальне буття.

Проте варто зазначити, що не менш важливим аспектом у темі проактивних стратегій $€$ ефективність їх реалізації для адаптації особистості до соціальних умов існування. Так, у дослідженні Л.М. Коробки було показано, що використання проактивних стратегій може в окремих випадках призводити до виснаження особистісних ресурсів, це, своєю чергою, спонукає особистість повернутися до реактивної стратегії задля відновлення та збереження останніх [12]. Тому ми можемо говорити, що в процесі побудови життєвого шляху особистість має гнучко використовувати обидва типи стратегій, залежно від конкретної ситуації та можливостей самої особистості реалізовувати персональні життєві цінності.

В умовах суспільної нестабільності процес реалізації життєвих цінностей особистістю значно ускладнюється, оскільки такі умови створюють невизначеність у сприйнятті особистістю власного майбутнього. Тому у разі побудови життєвого шляху набуває значення діалогічна взаємодія особистості із персональним виміром буття, що включає у себе розуміння власних життєвих цінностей та здатність до їх реалізації у соціумі. Життєві стратегії ми визначаємо як способи реалізації особистістю життєвих цілей та цінностей. Останні потрібно розглядати діалогічно, враховуючи взаємодію об'єктивних умов життя із самою особистістю, її ресурсами та цінностями. Виділено дві протилежні по змісту життєві стратегії: реактивну та проактивну. Реактивна життєва стратегія спрямована на збереження стабільності життя за рахунок задоволення базових потреб, тоді як проактивна спрямована на зміну об'єктивних умов існування для розвитку як самої особистості, так і суспільства загалом. Тому можемо зробити висновок, що для підвищення якості життя особистості важливою є гнучкість у процесі взаємодії із соціумом. Це означає, що як реактивна, так і проактивна життєві стратегії доцільні залежно від завдання, яке ставить перед людиною конкретна ситуація, та ресурсів і цінностей самої особистості. Перспективою подальших досліджень буде з'ясування інших характерних особливостей життєвих стратегій особистості в умовах суспільної нестабільності, які тією чи іншою мірою допомагають особистості вибудовувати автентичний життєвий шлях.

\section{ЛІТЕРАТУРА:}

1. Соціальна регуляція поведінки в умовах суспільної нестабільності / ред. О. Злобіна. Київ : ІН-т соціології НАН України, 2013. 320 с.

2. Уварова С.Г. Сучасне суспільство у вимірі перманентної кризовості. Науковий вісник Херсонського 
державного університету. Серія: Психологічні науки. 2015. Т. 2, № 1. С. 113-119

3. Стан сучасного українського суспільства: цивілізаційний вимір / ред. М. Шульга. Київ : Ін-т соціології НАН України, 2017. 198 с.

4. Васина Е.А. Изучение жизненных стратегий с помощью методики «Пословицы». Интерактивная наука, 2018. № 11 (33), с. 8-12. URL: https://doi. org/10.21661/r-473959 (дата звернення: 03.06.2021).

5. Абульханова-Славская К.А. Стратегия жизни. Москва : Мысль, 1991.

6. Руденко О. Моделі-підходи до аналізу поняття «суспільна стабільність». Державне управління та місцеве самоврядування : зб. наук. пр. Дніпропетровськ, 2009. Вип. 1 (1). С. 22-33.

7. Лэнгле А. Что движет человеком? Экзистенциально-аналитическая теория эмоций. Москва : Генезис, 2016.
8. Ерзин А.И., Епанчицева Г.А. Понятие проактивности в современной психологии. Теоретическая и экспериментальная психология. 2013. Т. 6, № 1. C. 79-83.

9. Hongdang Meng. Social Script Theory and CrossCultural Communication. Intercultural Communication Studies. 2008. XVII. P. 132-138.

10. Ерзин А.И., Антохин Е.Ю. Апробация методики диагностики проактивности в клинических выборках. Психология и психотехника. 2015. № 5(80). C. 493-500.

11. Лэнгле A. Person. Экзистенциально-аналитическая теория личности. Москва : Генезис, 2017.

12. Коробка Л.М. Психологічні стратегії як засоби реалізації індивідуальної і колективної адаптації до наслідків воєнного конфрлікту. Наукові студії із соціальної та політичної психології. 2018. № 41. C. 46-56. 